\title{
ON THE SCYPHOMEDUSA PORALIA RUFESCENS VANHOFFEN
}

\author{
By F. S. RusSELL, F.R.S. \\ The Plymouth Laboratory
}

(Plate I and Text-figs. I and 2)

Vanhöffen (1902) described a new genus and species of scyphomedusa, Poralia rufescens, from one incomplete specimen. Subsequently ten specimens attributable to this species have been recorded (Bigelow, 1909, two; Vanhöffen, I909, one; Broch, I913, one; Bigelow, I938, three; and Ranson, I945, three). Not one of these specimens was complete.

In a series of deep horizontal hauls made with a $2 \mathrm{~m}$ stramin closing net on R.R.S. 'Discovery II' I have found twenty-four specimens. All the specimens were caught in the area $37^{\circ} 28^{\prime}-38^{\circ} 00^{\prime} \mathrm{N}$., II ${ }^{\circ} 59^{\prime}-13^{\circ} 46^{\prime} \mathrm{W}$., in August and September 1959.

All the specimens were imperfect, but fifteen of them were sufficiently complete to give definite information on certain characters, such as numbers of mouth-lips, of radial canals, and of gonads. Owing to their fragmented state and the fact that in none of them were the margins complete, it is only possible to give approximate overall dimensions.

The information available is given in Table $\mathrm{I}$, and for comparison the few data available in the literature are given in Table 2. Although, admittedly, some of the data given in Table I are uncertain, owing to the possibility that fragments are missing from some specimens, the results are nevertheless consistent.

It can be assumed that specimens between II and $70 \mathrm{~mm}$ in diameter will have 5-8 mouth-lips, and 20-38 radial canals. Medusae smaller than $35 \mathrm{~mm}$ in diameter probably have normally five mouth-lips, but the smallest specimens may have as many radial canals as the largest. The diameter of the stomach appears to be less than half the diameter of the umbrella, allowing for the fact that no specimen has a complete umbrella margin. While the gonadial folds can be seen to be developing in small medusae, the sex does not become apparent until the medusa is over $40 \mathrm{~mm}$ in diameter.

If these conclusions are compared with the data given in Table 2 there appears to be complete agreement, except for the one very large specimen recorded by Bigelow (I909), which had I8-I9 mouth-lips. If the latter is the same species it indicates continued increase in the number of mouth-lips as the medusa grows, but not of the number of radial canals.

The jelly of the umbrella thins out suddenly about half-way towards the 


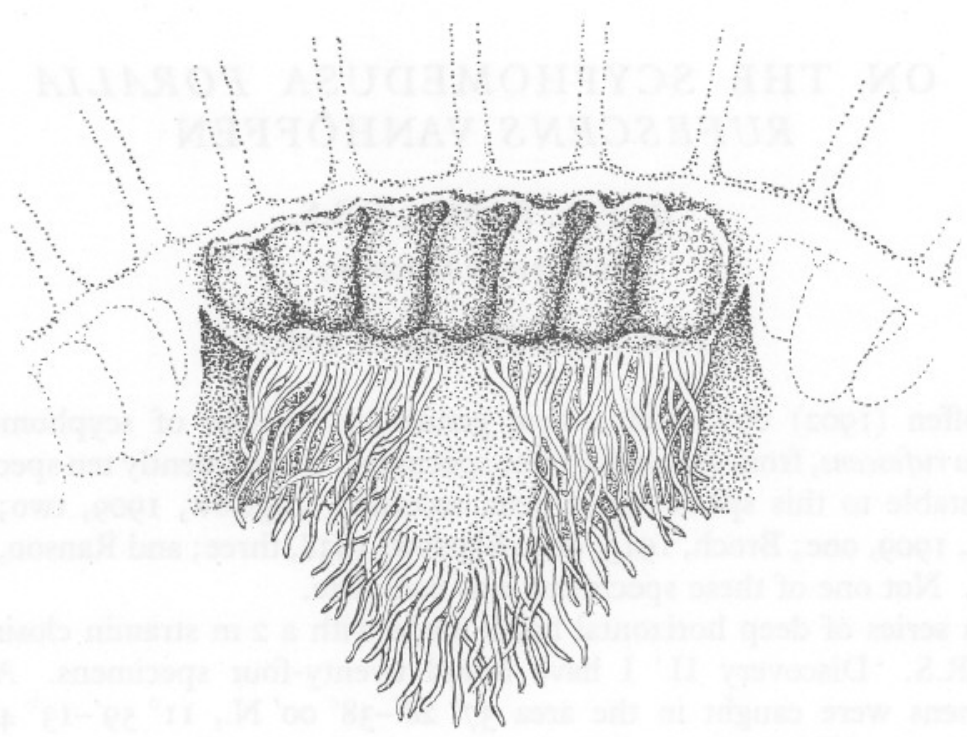

Text-fig. I. Poralia rufescens; gonad of male specimen about $70 \mathrm{~mm}$ in diameter, showing protrusion of stomach wall and gastric cirri.

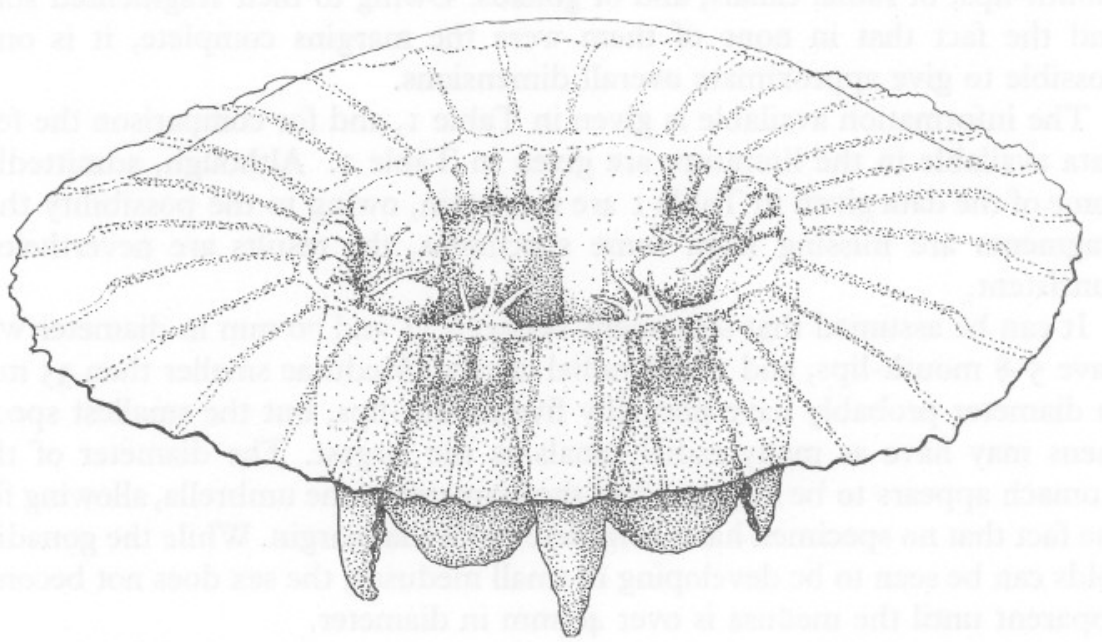

Text-fig. 2. Poralia rufescens; reconstructed drawing of typical five-lipped specimen. Only one or two gastric cirri are indicated. The entire margin of the umbrella is missing $(\times c a .2 \cdot 0)$. 
margin of the umbrella. This appears to be a weak point at which the umbrella may easily break and would account for the lack of entire margins in preserved specimens (Pl. I). In no specimens could I find rhopalia, owing to the damaged margins. The mesogloea contains numerous large cells as Ranson (1945) has already described. The colour is the reddish brown typical of deep-sea medusae.

In the gonads of the two females there were a few white eggs, the largest being I mm in diameter. Each gonad is a continuous ribbon thrown into folds by a series of alternating depressions and protrusions in the wall of the stomach (Text-fig. I). In the region of the gonad the stomach wall is thin, but it becomes thick and gelatinous a little below the gonads and is then nearly as thick as the gelatinous mouth-lips but not so firm in consistency. Immediately below each gonad the stomach wall protrudes into the stomach cavity to form a deep triangular pocket, and it is on the internal surfaces of these protrusions that the gastric cirri are set (Text-figs. I and 2). Seen from the exumbrella side the stomach is clearly pentagonal in shape in specimens with five mouth-lips.

Tables I and 2 show that Poralia rufescens is a true deep-sea species, whose normal habitat is evidently below $1500 \mathrm{~m}$.

My thanks are due to Mr P. Pring for taking the photographs reproduced in Plate I.

\section{SUMMARY}

A number of damaged specimens of the scyphomedusa Poralia rufescens Vanhöffen from the north Atlantic have been examined. This has added to our knowledge of this rare medusa, of which only eleven damaged specimens had previously been recorded.

Most of the specimens were caught deeper than $1500 \mathrm{~m}$.

\section{REFERENCES}

BigeLOW, H. B., I909. Reports on the scientific results of the expedition to the eastern tropical Pacific, XVI. The Medusae. Mem Mus. comp. Zoöl. Harvard, Vol. 37, pp. I-243 [p. 45, pl. I3, figs. I-5].

- 1938. Plankton of the Bermuda Oceanographic Expeditions. VIII. Medusae taken during the years 1929 and 1930. Zoologica, N.Y., Vol. 23, pp. 99-189. [p. 165].

Broch, H., I913. Scyphomedusae. Rep. 'Michael Sars' N. Atl. Deep Sea Exped.1910, Vol. 3, part I, I9I3 (reprinted I933), pp. I-24 [p. I9].

Ranson, G., 1945. Scyphoméduses provenant des campagnes du Prince Albert Ier de Monaco. Rés. Camp. sci. Monaco, Fasc. 106, pp. I-92 [p. 53, pl. II, figs. Io, II].

VANHÖFFEN, E., I902. Die acraspeden Medusen der deutschen Tiefsee-Expedition I898-I899. Wiss. Ergebn. 'Valdivia', Bd. 3, pp. I-52 [p. 4I, pl. IV, figs. I5, I6]. 
TABLE 1. PORALIA RUFESCENS COLLECTED ON R.R.S. 'DISCOVERY II': AUGUST AND SEPTEMBER 1959

\begin{tabular}{|c|c|c|c|c|c|c|c|}
\hline $\begin{array}{c}\text { Dia- } \\
\text { meter } \\
\text { of } \\
\text { umbrella } \\
(\mathrm{mm})\end{array}$ & $\begin{array}{c}\text { Dia- } \\
\text { meter } \\
\text { of } \\
\text { stomach } \\
(\mathrm{mm})\end{array}$ & $\begin{array}{l}\text { Num- } \\
\text { ber } \\
\text { of } \\
\text { mouth- } \\
\text { lips }\end{array}$ & $\begin{array}{l}\text { Num- } \\
\text { ber } \\
\text { of } \\
\text { radial } \\
\text { canals }\end{array}$ & Sex & $\begin{array}{c}\text { Maxi- } \\
\text { mum } \\
\text { number } \\
\text { of } \\
\text { large } \\
\text { gonadial } \\
\text { folds }\end{array}$ & $\begin{array}{c}\text { Station } \\
\text { number }\end{array}$ & $\begin{array}{l}\text { Depth } \\
\text { (m) }\end{array}$ \\
\hline II & - & $? 5$ & 28 & - & - & 4246 & 1770 \\
\hline II & - & - & 38 & - & - & 4246 & 1810 \\
\hline- & 6 & 5 & 20 & - & - & 4246 & I 770 \\
\hline I2 & 6 & ? 4 & $? 25$ & - & - & 4254 & 1680 \\
\hline 15 & I0 & ? 5 & 30 & - & - & 4246 & 1770 \\
\hline 22 & $\mathrm{I} 2$ & - & 20 & - & - & 4232 & 1600 \\
\hline 24 & 12 & 5 & 20 & - & - & 4232 & 1600 \\
\hline - & I5 & - & ? 30 & - & - & 4254 & 1370 \\
\hline 33 & 16 & & 32 & - & - & 4254 & 1680 \\
\hline 40 & 一 & ? 6-8 & ? 29 & - & - & 4232 & 1200 \\
\hline & 25 & 8 & - & - & - & 4246 & 950 \\
\hline & 27 & 5 & 24 & 우 & 4 & 4246 & 1810 \\
\hline 60 & 30 & 6 & - & - & - & 4254 & 1680 \\
\hline 70 & 2 & $? 6$ & $? \overline{32}$ & 0 & 4 & 4232 & 1600 \\
\hline 70 & 35 & 5 & 29 & $0^{*}$ & 8 & 4254 & 1600 \\
\hline
\end{tabular}

TABLE 2. PREVIOUS RECORDS OF PORALIA RUFESCENS

\begin{tabular}{|c|c|c|c|c|c|c|c|}
\hline $40 \times 67$ & $20 \times 33^{\star}$ & 7 & ? $2 \mathrm{I}$ & - & 3 & Vanhöffen (1902) & IIOOV. \\
\hline 250 & $105^{\star}$ & $18-19$ & $4 \mathrm{I}$ & - & - & Bigelow (1909) & $3658 \mathrm{v}$. \\
\hline 75 & & ? 8 & ? 40 & - & - & Bigelow (I909) & $549 \mathrm{v}$ \\
\hline & 一 & - & 32 & - & - & Broch (I9I3) & $1100-2000 \mathrm{c}$ \\
\hline - & 30 & - & 40 & - & - & Bigelow (1938) & I646 \\
\hline - & 35 & 5 & 30 & q & 6 & Bigelow (1938) & 1829 \\
\hline - & 18 & $\frac{3}{5}$ & 38 & \pm & - & Bigelow (1938) & 1463 \\
\hline $25-30$ & - & 5 & - & - & - & Ranson (1945) & $2000 \mathrm{v}$. \\
\hline - & 35 & - & - & 一 & - & Ranson (1945) & $2000 \mathrm{v}$. \\
\hline
\end{tabular}

\section{EXPLANATION OF PLATE I}

Poralia rufescens; photographs of female specimen $55 \mathrm{~mm}$ in diameter (Discovery St. 4246). Above: subumbrellar side showing five mouth-lips and large eggs in gonads; below, exumbrellar side; much of the outer periphery of the umbrella has broken away at the point where the jelly becomes thinner. (Enlarged $\times c a .1 \cdot 75$.) 


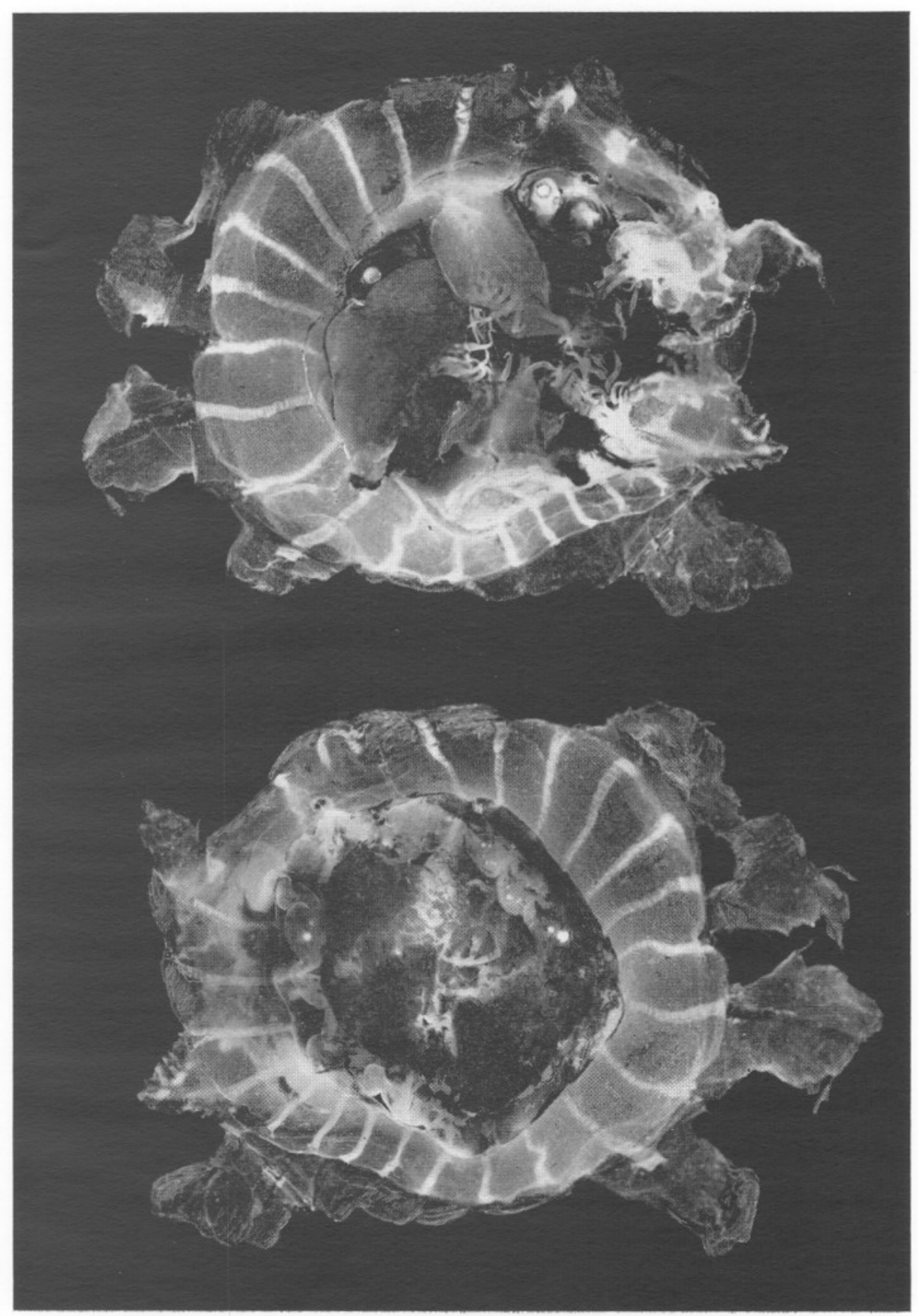

(Facing p. 390) 